\title{
Australia and Asia-Pacific security after September 11: an introduction
}

\author{
David W. Lovell
}

The aim of this collection is to examine the long-term security issues and challenges in the Asia-Pacific region, with particular reference to Australia and its regional role. The Asia-Pacific is large and diverse, and has only recently begun to acquire a sense of itself as a distinct region, committed to a security dialogue. Since the end of the Cold War a positive regional role for Australia has become as imperative as it is difficult. This book is designed chiefly for those involved in the policy-making process. It therefore tries to avoid scholarly jargon as much as possible, but it tries also to be clear and precise in what it says.

At least two major assumptions were made in putting together the brief for this work: first, that Australia can have, and should have, an important role in the region (though it may not be decisive); second, that the core strategic realities are for the foreseeable future bound up with the dispositions of China, Japan and the United States. How Australia might rise to the challenge of a constructive regional role in light of the realities of power, and in light of its long and dismal record of relative uninterest in the region, is a matter that exercises politicians, foreignpolicy professionals and academics alike. It calls for intelligence and sensitivity, for a modulated approach to Australia's key alliance relationship with the United States, and for a clearer definition of the goal of regional engagement. In the sometimes volatile arena of world politics - and especially when the powerful demand that others make a choice between 'us' or 'them'--intelligence and sensitivity are put to the severest test.

There is little doubt that the Asia-Pacific region is of enormous importance to Australia, in that it encompasses the bulk of Australia's trade, is a source of diverse cultural influences, and is inextricably bound up with Australia's security. But in engaging with the region, there is a pervasive sense among commentators 
that Australia has handled the challenges, on the whole, rather poorly. Australia is a rich country that looks both miserly and cruel in its treatment of refugee claimants, and has acted with little sensitivity in relations with South Pacific states, even passing on its refugee problems to some of them. It appears too eager to go to US assistance in the 'war on terror', and has blundered in some of its public pronouncements on pre-emptive strikes against possible terrorist threats against Australia. And its relations with its closest neighbour remain damaged after East Timor's independence, at a time when Indonesia could do with some support in its democratization process. Whatever the rights and wrongs of each of these points, Australia appears remote from regional feelings, and is regarded as a fair-weather friend to regional states.

In their various ways, the contributors to this book have addressed the realities and particular challenges confronting the region and Australia. This introduction will outline some of the main themes examined in the book, but it will also discuss the security implications of the current 'war on terror', and how they relate to the long-term strategic realities in the region. The 'war on terror', important though it may be, threatens to obscure the long list of security concerns that remain pressing and contentious. And this new 'war', by appearing to be a war on Islam, threatens to widen the gulf between Australia and its neighbours. Now is the time for calm thinking about long-term interests, and intelligent diplomacy in their service.

\section{The changing security agenda}

Even before the end of the Cold War there was a growing awareness that traditional understandings of security-as chiefly a matter of secure national boundaries, defended by military force-were inadequate to describe the range of threats to states and peoples. Non-traditional threats to security encompass a range of matters, from ethnic and religious conflict, people-, drug- and arms-smuggling, through terrorism, environmental degradation, deforestation and water scarcity, to transnational crime and natural disasters (Chalk 2000). They cross borders with impunity; they cannot be solved by individual states, nor by the employment of armed forces alone. Non-traditional threats to security have the potential to destabilize states and whole regions (Dupont 2001). Maintaining security is no longer simply about defending the state from armed invasion by other states.

Such a broadened understanding of security means that we must look not just to a range of new threats to national security, new ways of dealing with those threats (where military might is not always appropriate), and new (non-state) actors in security matters. It means that we must consider the goals of security as consisting of the safety and well-being of individuals (Buzan 1991) and the stability of regions, as well as the territorial integrity of particular states. The reference points of 'security' have changed. We need also to ensure that 'security' itself, despite its expanded meaning, continues to have a genuine content, and does not simply become an all-embracing 'hurrah!' word. 
Though the "new security" models originated among theorists, they are beginning to have a wider currency among policy-makers because they represent matters of genuine concern. Theory, as theorists rightly keep telling us, is essential to policy-making, and even unreconstructed pragmatists have some theory of international relations or security on which they (often unconsciously) rely. The theory provides a framework within which empirical material is chosen, examined, sorted and arranged. Theories give us clues about what to look for, what is 'significant', and what is expected (they therefore help us to recognize the unexpected). As Joseph Nye $(1989,339-40)$ has explained, 'Theory ties facts together. It helps the policy-maker to understand and predict. Even the most pragmatic policy-makers fall back on some theoretical constructs because neither all the facts nor their relationships are ever known'. Without good theory linking parts of the larger picture together, we are like the six blind men who each examined a part of the elephant, and did not recognize that it was an elephant.

Studies of contesting theoretical approaches to international relations--realism, neo-realism, liberalism, behaviouralism, and so on-may seem to get bogged down in abstruse jargon, and may have only a limited utility in generating predictions, but they are nevertheless important in our overall understanding of security situations. Though this book is not primarily about theoretical debates, except in so far as Chen Dongxiao explores how constructivism might help policymakers to understand better the realities of Asia-Pacific security, each of the chapters implicitly challenges policy-makers to be self-conscious about their assumptions, preconceptions, and perspectives. Being theoretically self-conscious also means being culturally self-conscious, since the major tools we have for analysing inter-state relations have grown out of European experience, and the balance of power assumptions at the heart of realism, for example, may not translate easily into the Asia-Pacific situation - a point well made by Baker and Sebastian (1996).

The new security issues raise particularly intense challenges for the AsiaPacific region (Tow, Thakur and Hyun 2000, Part 3). The whole range of 'human security' issues are present here, as are the difficulties of identifying whose responsibility they are. Indeed, the Asia-Pacific region throws into sharp relief the tension between 'sovereignty', on the one hand, and intervention on behalf of human security matters, on the other. For 'sovereignty' is a way of quarantining issues, of locating the state responsible for particular issues, and of saying to others: this is our business, keep out! This view of sovereignty and the related notion of non-intervention has been at the bedrock of international relations since the Treaty of Westphalia in 1648.

The new security agenda cuts across this old assignment of responsibilities-and it is important to note that 'sovereignty' implies not just rights to adjudicate within a territory, but also responsibilities - and creates considerable consternation over whether it may give a licence to meddling and interference. Where should the line be drawn about when outside intervention is 
justified, and when it is not? In whose interests can intervention be undertaken, and whose culture and values will prevail? In all these respects, human security concerns create problems for states and non-state actors trying to deal with them. Yet to insist on 'sovereignty' in the face of pressing transnational issues often means that no-one will take responsibility for addressing or solving them.

The new security agenda highlights legitimate areas of cross-border concern, but Asia-Pacific states have responded cautiously to its imperatives. Nonintervention in the affairs of others is an established part of the practice of the Association of South East Asian Nations (ASEAN), but states are beginning to recognize their complex interrelations and to cooperate in numerous areas (Funston 2000). Caution is understandable, since in some respects the new security agenda might become a recipe for enlarging the scope of issues over which conflict may occur. The key issue, therefore, is how intervention can be advanced in ways that are not destructive of existing inter-state relations. Thus, reconceptualizing 'security' to take greater account of the individual, human dimension as well as the state does not mean that security is any easier to achieve. The United Nations' intervention in East Timor (with the major impetus from Australia, but with the participation of a number of Asia-Pacific states) was perhaps a triumph of humanitarian intervention, but it continues to sour relations between Australia and Indonesia.

The rethinking of 'security' is slowly but surely feeding into security practice in the Asia-Pacific. It has paralleled the emergence of the region's sense of itself, as it becomes more committed to the institutionalization of a regional security dialogue. Des Ball (1996) has argued that institutionalization of the confidence and security-building measures (CSBM) process in the Asia-Pacific is a major step forward in the region, and was previously thought unachievable. The rapidity of this change gives hope that even more can be done. Meetings of government officials in the so-called 'first-track' process-the forum of Asia Pacific Economic Cooperation (APEC) and the ASEAN Regional Forum (ARF)-have been joined by non-goverument meetings and workshops in the 'second-track' process. The Council for Security Cooperation in the Asia-Pacific (CSCAP), established in 1992, discusses traditional security matters as well as supporting formal working groups on "Transnational Crime" and on "Comprehensive and Cooperative Security'. But it remains true that ASEAN must do a great deal more if it wants to become a genuine security community; in particular, it must move beyond the existing CSBMs to preventive diplomacy. The courage to take that step is still some time away. In the meantime the region, like the world, has become transfixed by US responses to the dramatic terrorist attacks of what is popularly known as '9-11'.

\section{The region since September 11, 2001}

On the morning of September 11,2001, two large passenger aircraft were hijacked and flown into the towers of the World Trade Center in New York City, a third 
aircraft was flown into the Pentagon building near Washington, DC (the home of the US Defense Department), and a fourth crashed in a field in Pennsylvania, apparently foiled in the attempt to be used as a missile against the Capitol building in Washington. These attacks led to the deaths of nearly 3,000 people, of diverse nationalities and religions.

The hijackers were soon identified as members of an extremist Muslim terrorist network, al-Qa'ida, led (or at least greatly influenced) by a wealthy and charismatic Saudi, Osama bin Laden. Al-Qa'ida was based and trained in Afghanistan, and was supported by the government of that war-ravaged country. Osama bin Laden, while never claiming direct responsibility for the attack on the United States or articulating any immediate demands, nevertheless made it clear that this was part of a war between 'Islam' and 'the west'. This war had unknowingly been 'declared' by the bombing of US embassies in Nairobi, Kenya and Dar-es-Salaam, Tanzania in August 1998, and by the suicide bombing in Yemen of the American warship USS Cole in October 2000.

This series of events, but especially the destruction of the World Trade Center (WTC), was dramatic and shocking, and caught US intelligence and lawenforcement agencies-embroiled in 'turf-wars' and personality clashes-unprepared. The WTC impact and collapse were televised, and repeated again and again. They struck at the symbolic centres of US power. But most of all, they struck at the very core of the American psyche. For Americans, wars and battles occurred elsewhere, in other parts of the world. Their homeland, secure through every war in the twentieth century, was no longer untouched. The "war on terror' has now become an American preoccupation.

Regional reactions to the September 11 attack varied. The Australian Prime Minister, who was in Washington, DC on the very day of the attack, responded quickly and strongly in support of US efforts to track down and destroy the perpetrators and their backers. He cited the 1952 ANZUS Treaty as the basis on which Australian support for the United States could be justified. In Australia itself there was incomprehension mixed with outrage against the terrorists. Many governments and intellectual elites in the Asia-Pacific region were formally supportive of the United States---even if spurred to comment by the US demand that everyone must take sides-and were concerned about the stirrings of radical Islam within their own communities; but many ordinary citizens seemed to have rather mixed feelings, including the view that the United States deserved terrorist punishment. The latter response reflects a widespread resentment at US power, both military and economic, which is experienced as arrogant. Pakistan-which had formerly been a pariah because of its military dictatorship and support for the Taliban regime in Afghanistan-regained some international standing (and considerable aid) by assisting the United States against terrorist bases in Afghanistan. Other states paid greater attention to detecting and combating Islamic extremist groups in their midst. 
The terrorism associated with extremist Islam will not simply disappear with the demise of the Taliban, or any other, regime. It is born of despair, poverty and helplessness, and is channelled by fanatical Muslims who, according to Malaysia's Prime Minister Mahathir Mohamad, have misinterpreted and deliberately ignored the peaceful teachings of Islam (Mahathir 2002). This is one reason why leadership is needed to translate Muslim hostility against 'the west' into a program for self-reliance and pride. It is also the reason why a 'war' on terrorism is misleading either as a description or as a metaphor. The causes of terrorism cannot be eradicated militarily. The continuing terror campaign of Islamic extremism was duly confirmed in October 2002 , when a nightclub popular with western tourists in the Indonesian resort of Bali was bombed, and more than 190 people from 18 countries died in the explosion and subsequent fire. The group responsible for this attack, Jemaah Islamiyah, has links with al-Qa'ida.

The Bali bombing put an end to the scepticism which had earlier greeted US claims that the Asia-Pacific region was a base for terrorism. But terrorism is a security issue only partly in the narrow, military sense of that term. It is also, and perhaps more fundamentally, a human security issue. For the main reasons for the rise of extremist forms of Islam can be found in the continuing poverty and deprivation of many people in states that have significant Muslim populations. These states have proved to be fertile ground for recruits for terrorist groups, who find readily available images of a prosperous and decadent west to feed the resentment of their own powerlessness. The rise of extremist Islam can also be seen as a consequence of the disastrous Soviet invasion of Afghanistan, from 1979 to 1990. Muslim groups began organizing against the Soviets, and continued when they had left, a struggle which ultimately resulted in the Taliban regime and its alQa'ida partners.

The initial regional responses to the attacks of September 11 meant that many countries jumped onto the US-led bandwagon against terrorism. There were many advantages for joining, at least rhetorically, the 'war on terrorism'. China's relations with the United States-under great pressure over the 'spy-plane' collision earlier in 2001 -thawed after China's expressions of regret over the attacks. The United States lifted sanctions against India and Pakistan, imposed after they had tested nuclear weapons in May 1998. The Philippines gained US military advisers to help in its continuing struggle with bandits, now dubbed 'terrorists'. There were, of course, different levels of support in the region for the US military campaign in late 2001 against the Taliban regime in Afghanistan (Operation Enduring Freedom), with only Australia and Japan supplying military forces. And there has been much less support for the imminent US-led war against. Iraq, not just because of doubts about the extent of Iraq's program for weapons of mass destruction (WMD), nor simply because of widespread scepticism about the Iraqi regime's support for terrorist groups such as al-Qa'ida, but also because there is no evidence of an immediate danger to the United States from Iraq. For the 
United States, the 'war on terror' seems to have become a ready excuse for furthering existing campaigns.

It is not just the Americans for whom 'terrorism' has become a convenient label. In the Asia-Pacific region, there is a fear that the looseness of the term can be used by governments to stifle political dissent. Some states-notably Malaysia and Singapore-have imprisoned suspects under their respective Internal Security Acts, after apparently foiling bombing plots. But the lack of trials and public evidence in these cases unavoidably raises suspicions about the motives behind the arrests. Using the threat of terrorism to manipulate domestic political outcomes, rather than addressing genuine security concerns, is undoubtedly a temptation. Other states, notably Indonesia, denied that terrorism was a problem. The Bali bombing put an end to that complacency, and has seen the Indonesian authorities taking a much more active stand against terrorist suspects within the country. And in the aftermath of the Bali bombing, there has also been an extraordinary level of cooperation between police forces, especially the Australian Federal Police and Indonesian police, in tracking down the bombers.

Terrorism is a method of struggle to achieve political objectives. It has been used by the advocates of many political ideologies, and is not confined to any one. There have been many attempts to define it exhaustively over the past 18 months, and many of these have foundered on details. But this imprecision does not hide the fact that terrorism has been with us for a very long time, that it tends to be a weapon of the weak (a fact acknowledged in the current descriptions of 'asymmetric warfare'), and that as a method of struggle it will be with us for a long time to come. Terrorism associated with extremist Islam is the result of deeply disaffected young people in Muslim countries, disgusted with the poverty of their own countries, and their own powerlessness; they believe that western exploitation accounts for their situation. If the globalization championed by the west seems to make their situation worse, it also gives them tools to fight back, in that money, people and ideas now flow readily across borders, nourishing the networks of terror that confound (western) hierarchical notions of organization and authority.

\section{Change and continuity}

Much has changed, but much remains the same, since September 11, 2001. It is true that many other issues and concerns have been pushed off the front pages of newspapers, and that some existing problems have been reformulated as problems of terrorism; but the other concerns have not disappeared. What has changed is that there is an almost overwhelming urgency about terrorism, and a gearing up of intelligence, policing and military preparations for potential terrorist attacks, which are all the more fearsome in the public mind for being unpredictable, arbitrary, and indiscriminate. 
It is notable that until September 11, the preoccupation of security thinkers was over proposals by the administration of then-new US President George W. Bush to revive anti-missile missile development, under the rubric of 'national missile defence' and 'homeland security'. Many were concerned that American signals on this issue, and Australian support for them, were unnecessarily raising the strategic temperature in the Asia-Pacific region, could be interpreted as a strategy for the 'containment' of China, and were likely to lead to a deterioration of the security scene in the region. It hardly needs saying that in diplomacy, as in much else, the intentions of the communicator are much less important than the way messages are understood by the audience. 'Homeland security' has, following September 11, been given a distinctly anti-terrorist emphasis by the Americans (and now has a government ministry devoted to it), but the work on anti-missile missile technology continues, as does the appeal of an isolationist, fortress-like, mentality. Both the latter seem deeply unhelpful to the anti-terrorist cause, and to the larger cause of security in the Asia-Pacific, in which the United States has a direct interest.

The United States is now mobilized and interested in the matter of 'terrorism' (though it is actually more interested in a particular terrorist campaign). There is, in other words, a change of priorities. That change has major ramifications. What the United States thinks is important, is important. In addition, and linked to the 'war on terror', is a change of thinking about the use of force, operational concepts, and capability requirements. Defence forces will no doubt make the most of the current opportunities to convince their governments of the need to buy new equipment and raise their intelligence capabilities.

The issue of change and continuity has also arisen in a new debate about Australian strategic doctrine, which has for 15 years or more been associated with continental defence and the interdiction of hostile forces in the 'air-sea gap' between Australia and its northern neighbours (Dibb 2002). Such a doctrine has meant a steady downgrading of the size and capability of the army, and a boost to sea and air power. It is now being challenged by those who point to the record of Australian military involvements during the past 10 to 15 years, centred on peacekeeping but also in support of US operations, which have relied heavily on the army (Dupont 2002). Australian military practice has not changed fundamentally since September 11, but there is a growing view that strategic doctrine might have to put more emphasis on army capability and the reality of remote deployments. The official Australian Defence Update (Department of Defence 2003), released late in February 2003, reflects that view.

But what does all this really mean to the practice of world politics? The early turn by the United States after September 11 to multilateralism has been followed by a return to the underlying unilateralism of US foreign policy. Indeed, extensive worldwide opposition to the imminent war in Iraq has underlined the US sense that it is compelled to 'go it alone', and that it has a historic mission to accomplish. As Waltz has persuasively argued on this issue, "New challenges [for the US] have 
not changed old habits' (Waltz 2002, 348-49). More worryingly, 'terrorism' has provided the catch-all phrase that can justify what the United States already wanted to do. In Waltz's view, terrorism does not change the basic facts of current international politics: the imbalance of world power; the importance of nuclear weapons; and the persistence and accumulation of crises (Waltz 2002, 350-52). The US stance on Iraq's WMD program has thus far involved the United Nations, but the United States is clearly prepared to act (in effect) unilaterally, which would be a major blow to the international system. War in Iraq would also open Pandora's box on the issue of pre-emptive strikes, the US position on which was outlined in its recent National Security Strategy (National Security Council 2002).

The events of September 11 have not changed the fundamental strategic dynamics in the Asia-Pacific region, even if they have added another dimension to strategic issues and national security concerns. What further complicates the picture is that inept responses to the terrorist threat by the United States (or by Australia) will excite ethnic and religious passions in the region, and exacerbate the problem of terrorism.

\section{The strategic picture}

Whatever the situation with terrorism in the region, certain continuing strategic realities must be acknowledged: US power; the rise of China as a regional player; and the persistence of a number of tensions and dangers.

The United States is the world's only superpower since the end of the Cold War and the collapse of the Soviet Union in 1991. Its military power is extraordinary, and its technology makes it even more potent. It has the capacity-for the first time in history-- to know and respond to the events of the battlefield as they happen. (If Tolstoy's War and Peace is of any interest to modern strategic thinkers it is in its lesson of the enormous confusion of the battlefield.) This hegemonic US power is a fact of great concern to many in the world, who fear that the United States will act unilaterally in its own interests, intervening in other countries and overthrowing regimes as it sees fit. The current campaign against Iraq is widely seen as a litmus test of this proposition. While the United Nations was often paralyzed by the power play between the US and the USSR during the Cold War, it is now dealt into some world problems only by the good grace of the United States-and that cannot always be guaranteed.

China is emerging as a regional power, with claims for a larger role. It formally joined the World Trade Organization at the end of 2001, and will certainly become an economic giant by mid-century, if not before. China and the United States have different visions on a range of issues about sovereignty, alliances, and security mechanisms. The rise of China adds to issues about the balance of power in the region, and makes the US-China relationship a key factor in regional stability,

As for dangers, there are sites of tension throughout the region: on the Korean peninsula, in the Taiwan Straits, in the South China Sea, and in Kashmir. There are 
also transnational issues about water supply, pollution, piracy, arms- and drug smuggling, and organized crime. In terms of weapons of mass destruction, the Asia Pacific region is unfortunately well supplied. Five of the world's nine nuclear-armed powers are here: Russia, China, India, Pakistan and North Korea. Many of the regional states possess chemical and/or biological weapons. And delivery systems-especially ballistic missile systems-are widely held. The possibility for tensions turning to crises remain high.

The Asia-Pacific region also faces the problems of weak states: those going through difficult democratic transitions, such as Indonesia; and the problems of failed states, such as the Solomon Islands, where the state can no longer enforce order. Such states are an invitation to criminals and opportunists of all types, and are breeding grounds for separatist struggles. Given that the Asia-Pacific includes some of the world's most important seamlanes, maritime issues also remain important.

Among other issues that need attention are the continuing increases in regional defence expenditures since the Asian economic crisis of 1997-99, and the possibility of an arms race. While earlier increases in arms expenditures in the region may not have constituted an arms race (Wattanayagorn and Ball 1996), current expenditures are difficult to interpret otherwise. September 11 supplies an added rationale for increasing already high defence expenditures in the region, acquiring new defence capabilities, and increasing intelligence capabilities.

The Asia-Pacific is a region that contains diverse countries, but many of these already have significant defence capabilities: land, air, and maritime. China now has the third-largest defence expenditure in the world, and may soon overtake Russia (currently the second) (IISS 2001, 188-91). The capabilities demonstrated by US forces in the Gulf War in 1991, and developed to a very high degree in Afghanistan in 2001, are attractive to regional militaries. Regional states want to be able to take advantage of the 'Revolution in Military Affairs' and the associated information warfare. These include command, control and communications systems, unmanned aerial vehicles, precision guided munitions, and intelligence collection, particularly signals intelligence (from both land-based and airborne platforms). Many countries are acquiring these capabilities.

The Asia-Pacific region has countries that contain substantial Muslim populations, Indonesia being the largest Muslim country in the world. It is important for relations with the United States-which regional countries do not want to see leave the region - and for the internal stability of many of these countries, that US responses to extremist Muslim terrorism are not seen as a wholesale attack on Islam. So far, that has been very difficult to achieve, with US rhetoric sometimes echoing the bloody Christian crusades of a thousand years ago.

The effects of the terrorist attacks of September 11, and of US responses to them, are neither straightforward nor easily charted. The 'war against terror'-perhaps in part because of its somewhat inappropriate title-will be a 
long one, with many twists and turns. The effects will be military, but given the absolute predominance of US military might, they will fundamentally be political. Perhaps the United States will learn the hard way a lesson that Thucydides drew 2,500 years ago: that the greatest use of power is restraint. Indeed, US reactions to al-Qa'ida, rather than the methods and aims of al-Qa'ida itself, threaten to become the major issue. The military response to terrorism is almost calculated to exacerbate the problem because it does not address its roots.

Nor should it be assumed that the general revulsion against terrorist methods and aims will translate easily into regional cooperation. Terrorism is, in some senses, simply another issue which provides the potential for cooperation and conflict in regional relationships. We have already seen a good deal of evidence of both.

Regional security organizations are now challenged to make sure that while they manage the issue of terrorism, they do not lose sight of the pre-existing security issues. And indeed, terrorism poses a direct challenge to the region's security mechanisms, to move beyond the level of building confidence through discussion to problem solving and preventive diplomacy. Bilateral responses have been the primary response to the threat of terror and the US call to arms, though the ASEAN Regional Forum has begun to canvass the issues. Nevertheless, multilateralism now seems to be on the defensive across the world.

\section{Organization of this book}

This book begins by outlining the basics of Australian regional policy. Lovell's chapter makes a salutary plea for those engaged in the making and implementation of foreign policy to keep their eye on the larger picture, and especially to question easy assumptions about national interests, and about the obligations imposed by international friendships. James Cotton examines the background to Australia's regional policy, especially since the end of the Cold War emphasized the need for Australia to redefine its relationship with the region; he focuses on the travails with Indonesia over the issue of East Timor's independence as perhaps the most serious test of Australia's foreign policy in decades. He asks whether regionalism or globalization is the major force at work in Australia's responses to Asia-Pacific issues. Allan Behm, not long retired from Australia's Department of Defence, provides a practitioner's insight into thinking about China's strategic policies, looking for continuity in the long-term with Sun Tze, and exploring Australia's strategic options.

The contributions go on to focus on the role of China. It is a feature of this work that it includes a number of chapters by distinguished Chinese scholars that reflect the way that China perceives its growing position in the region. Not surprisingly, these scholars see a legitimate regional role for a power that is currently substantial, and will one day be enormous. China's leaders resent efforts by others, and particularly the United States, to keep them out of a rightful place in 
the international security regime. Zhu Majie makes the point that China has a role to play in the security mechanism of the Asia-Pacific, and sets down some major guidelines in furthering security. Xia Liping argues that China has used its power in a responsible and constructive way. Tian Zhongqing reinforces these contributions by explaining the changing nature of China's economy. An increasingly knowledgembased economy brings China squarely into the international economy, and explains its need to participate fully in the security dialogue.

China's foreign policies are then examined from different perspectives. Carl Thayer examines the doctrinal basis for Chinese relations with Southeast Asian states, and argues that behind much of the new thinking about partnerships within the region is a fairly constant concern with containing US power. The US-China relationship is crucial to the long-term stability of the region, troubled though the relationship is in the longer term by the handling of Taiwan, and the military buildup adjacent to Taiwan in Fujian province, and in the shorter term by accidents or misunderstandings, such as the collision between the US EP-3 spy plane and a Chinese F-8 fighter jet on or near Chinese territorial boundaries in April 2001. Jian Zhang explores the domestic pressures in China's foreign policy, using the examples of the Belgrade embassy bombing by US planes and the spy plane collision to argue that a groundswell of Chinese nationalism, prepared by the ruling communist party, has sometimes to be kept in check by authorities in order to maintain workable foreign relations. For China's leaders, Chinese nationalism is proving to be a two-edged sword.

The contributions then turn to examine other regional matters. Aaron Matthews reminds us, as indeed North Korea keeps reminding us, that instability on the Korean peninsula remains a serious issue, and impacts on Japan's delicate strategic balancing act between China and the United States. For all its bluster-missile development, withdrawal from the International Atomic Energy Agency agreement, as well as a substantial armed force-the world's only remaining Stalinist state is seriously weakened by starvation and economic deprivation. As one of the few countries with diplomatic ties with North Korea, Australia was the first to engage the North Koreans diplomatically after the recent reactivation of the nuclear plant capable of reprocessing spent nuclear fuel for weapons purposes, and may yet help to resolve US-North Korean tensions. William Maley brings some perspective to bear on the fast-moving developments in Southwest Asia, with US intervention in Afghanistan late in 2001, and simmering tensions between India and Pakistan over Kashmir. Southwest Asia is a part of the Asia-Pacific that tends to be neglected in Australia's security perceptions, except at times of tension, but it deserves far more considered attention because of the threat of nuclear war and the uncertainties created by weak and failed states, but especially because of the India's enormous potential as an economic and technological power-house. Michael Wesley examines the security architecture in the region, arguing that regionalism is a way that countries in the Asia-Pacific have responded to US-led 
global order, and that the current malaise in regional organization is due to the uncertain nature of the intensified forces of globalization, and will likely persist for some time.

Chen Dongxiao examines the constructivist model as a way of understanding the security prospects in East Asia. In the face of the pessimism of traditional analytical frameworks, Chen finds some cause for optimism on the constructivists" grounds that in redefining its identity within the region China will take a more pronounced role in multilateral security arrangements. The work ends with an examination by William Tow of the ANZUS alliance, which is crucial to the way Australia perceives its international relationships. In some respects, this alliance-explicitly and emotionally reaffirmed by Australia's Prime Minister, John Howard, after September 11-is the key to Australia's regional dilemmas.

\section{Conclusion}

Australian foreign policy professionals need an unsentimental look at the present, where Australia's role as a regional 'player' is limited and only grudgingly accepted. The East Timor issue has been a test of Australia's regional engagement (Chalk 2001), a test it (and not merely any particular government) has failed. Australia's policy has in recent years been rightly described as moving from 'engagement' to ambivalence (Cotton and Ravenhill 2001, 4). The situation is positive in as much as there is debate in policy circles over Australia's stance in the region, but negative in that such debate is increasingly tinged with domestic, partisan considerations. 'Engagement' was the cry of successive Australian governments, Labor and Coalition (Cotton and Ravenhill 1997, 9), but the practicalities have been much more difficult to manage. And unreasonably high expectations have made the reverses all the more disappointing.

Responding to the threat of terrorism compounds the challenges for Australian policy-makers. An inappropriate response is one which overestimates the danger of terrorism, downplays other regional issues, alienates regional states, and sours the views of moderate Muslims, who form a key part of these states. Policy. makers should not be fooled into thinking that everything has changed since September 11, and must keep their focus on building strong long-term relations with Asia-Pacific nations. They should be guided by a clear sense of what sort of relationship Australia can build with the region. 'Engagement' was perhaps a necessary way of describing Australia's stronger turn to the region, but it has become a cliché. We need other terms, but we also need deeper contacts with the region across all levels of government, business, and academia to make the connections more realistic and resilient.

The terrorism associated with extremist Islam will be with us for many years, and perhaps decades, to come. There will be political, military, and intelligence responses (but, sadly, perhaps fewer economic responses). Old problems remain; new challenges arise. But the challenge of prioritizing these issues, and handling 
them with the same sense of regional sensitivity, is more important than ever before.

To make the judgement that strategic realities since September 11 are much the same as before does not mean that regional security is any easier to deal with. Security matters often seem to be fleeting. Issues-mproblems-come and go quickly on the agenda. In some cases, and especially to practitioners, foreign affairs seems to be an example of triage: just like the casualty ward of a busy hospital, the doctors - the foreign policy makers-are compelled to sort out the priority of bleeding emergencies on the trolleys before them. Such an image, even it captures some of the flavour of the main desk in a foreign ministry, should not be allowed to overwhelm attention to the larger, more considered, stance. Foreign policy is about setting priorities; but it is also about not forgetting the larger picture. The contrast between crisis management and long-term strategy has been well made by Hanson and Tow (2001, 5-7).

Theory, too, is important, but one should be cautious of long-term prognostications, encouraged by the (rather arbitrary) turn of the millennium. We have seen Francis Fukuyama's 'end of history' contribution, Samuel Huntington's (1996) 'clash of civilizations', and Paul Kennedy's (1987) 'imperial overstretch'. Such grand models are porous enough to admit all sorts of variations, and are therefore less useful than often supposed. Fukuyama (2002), for example, continues to insist that his thesis is correct, with radical Islam described as a backlash against modernity.

The concept of 'security' itself has been stretched to encompass non-traditional issues (particularly transnational ones) and non-state actors, but the old security concerns have not disappeared. Globalization may mean increasing interdependence between states, but states still matter. They insist, sometimes by force, that they are part of the process; their long life means that they are highly adaptable in the face of new challenges; and they continue to have legitimate coercive power. Nevertheless, governments must learn that non-government organizations have a place in the security dialogue, that different approaches to security are not always at odds, and that non-traditional security issues are ignored at their peril.

One does not have to be a 'realist'-in terms of International Relations theory-to believe that states remain important, both as building blocks of the international security system and as actors within it. But realism should not blind us to the salience of other security issues and of non-state actors. In some respects, the central theme of this work is that states in the Asia-Pacific region will continue to be the focus for identities and loyalties, and will continue to generate key security concerns as well as to sponsor the major forums in which such concerns will be discussed and mediated. Among those states, the influence of the United States will continue to be pervasive, both in its direct relations with regional actors, and in the indirect consequences of its own security preoccupations. Japan, China and, to a growing extent, India, will increasingly define the major concerns 
of the region as they interact diplomatically and interpenetrate economically and socially. The challenge for those who make and implement foreign policy in the region is to ensure that these interactions can occur with the least friction, that misunderstandings are overcome and genuine difficulties honestly addressed, and that the wide and important range of non-traditional security issues becomes a natural part of the security dialogue.

Australia's relations with the region are not as strong as many of us would like, or many of us believe are required. Australia begins in this relationship with a serious deficit, acquired by its history and the record of its immigration policies, and its current stance on asylum seekers. Likewise, its central and enduring alliance with the United States creates problems as well as opportunities.

Foreign policy must be informed by long-term considerations, and a strategic overview. Every decision has a number of complex ramifications. If Australian policy is guided by a consistent goal of better relations within the region; if it is informed by consultations within the region, and clear and direct information; then it will help Australia's role and improve the security of the region. If this book helps either to clarify the major issues, or to keep the eyes of policy-makers focused on the main game, then it will be a success.

\section{References}

Baker, Nicola, and Leonard C. Sebastian. 1996. 'The Problem with Parachuting: Strategic Studies and Security in the Asia/Pacific Region'. In Desmond Ball (ed.), The Transformation of Security in the Asia/Pacific Region. London: Frank Cass, pp. 15-31,

Ball, Desmond. 1996. 'Building Confidence and Security in the Asia-Pacific Region'. In Gary Klintworth (ed.), Asia-Pacific Security: Less Uncertainty, New Opportunities? Melbourne and New York, Longman and St Martin's Press, pp. 245-61.

Buzan, Barry. 1991. People, States and Fear: An Agenda for International Security Studies in the Post-Cold War Era. 2nd ed. London: Harvester Wheatsheaf.

Chalk, Peter. 2000. Non-Military Security and Global Order: The Impact of Extremism, Violence and Chaos on National and International Security. London: Macmillan.

Chalk, Peter. 2001. Australian Foreign and Defense Policy in the Wake of the 1999/2000 East Timor Intervention. Santa Monica CA: RAND.

Cotton, James and John Ravenhill. 1997. 'Australia's "Engagement with Asia"'. In James Cotton and John Ravenhill (eds), Seeking Asian Engagement: Australia in World Affairs 1991-95. Melbourne: Oxford University Press, pp. 1-16.

Cotton, James and John Ravenhill. 2001. 'Australia in World Affairs 1996-2000'. In James Cotton and John Ravenhill (eds), The National Interest in a Global Era: Australia in World Affairs 1996-2000. Melbourne: Oxford University Press, pp. 3-9.

Department of Defence. 2003. Australia's National Security: A Defence Update 2003. Canberra: Commonwealth of Australia.

Dibb, Paul. 2002. 'Defence Policy is on the Money'. The Australian, 13 November.

Dupont, Alan. 2001. East Asia Imperilled: Transnational Challenges to Security. Cambridge: Cambridge University Press. 
Dupont, Alan. 2002. 'A Nation's War on Terrorism'. The Australian, 14 November.

Fukuyama, Francis. 2002. 'History and September 11'. In Ken Booth and Tim Dunne (eds), Worlds in Collision: Terror and the Future of Global Order. Basingstoke: Palgrave Macmillan, pp. 27-36.

Funston, John. 2000. 'ASEAN and the Principles of Non-Intervention: Practice and Prospects'. In David Dickens and Guy Wilson-Roberts (eds), Non-Intervention and State Sovereignty in the Asia-Pacific. Wellington: Centre for Strategic Studies, pp. 5-18.

Hanson, Marianne, and William T. Tow. 2001. 'Introduction'. In Marianne Hanson and William T. Tow (eds). 2001. International Relations in the New Century: An Australian Perspective. South Melbourne: Oxford University Press, pp. 1-16.

Huntington, Samuel P. 1996. The Clash of Civilizations and the Remaking of World Order. New York: Simon and Schuster.

International Institute for Strategic Studies (IISS). 2001. The Military Balance 2001-2002. London: Oxford University Press for IISS.

Kennedy, Paul M. 1987. The Rise and Fall of the Great Powers: Economic Change and Military Conflict from 1500 to 2000. New York: Random House.

Mahathir, Mohamad. 2002. 'Muslim Unity in the Face of Challenges and Threats'. The Australian, 10 February.

National Security Council. 2002. The National Security Strategy of the United States of America.<http://www.whitehouse.gov/nsc/nss.html>.

Nye, Joseph. 1989. 'The Contribution of Strategic Studies: Future Challenges'. In François Heisbourg (ed.), The Changing Strategic Landscape. London: Macmillan in association with International Institute for Strategic Studies, pp. $327 \sim 41$.

Tow, William T., Ramesh Thakur and In-Taek Hyun (eds), 2000. Asia's Emerging Regional Order: Reconciling Traditional and Human Security. Tokyo: United Nations University Press.

Waltz, Kenneth N. 2002. 'The Continuity of International Politics'. In Ken Booth and Tim Dunne (eds), Worlds in Collision: Terror and the Future of Global Order.

Basingstoke: Palgrave Macmillan, pp. 348-53.

Wattanayagorn, Panitan, and Desmond Ball. 1996. 'A Regional Arms Race?'. In Desmond Ball (ed.), The Transformation of Security in the AsialPacific Region. London: Frank Cass, pp. 147-74. 